\title{
Predicting the current distribution and potential spread of the exotic grass Eragrostis plana Nees in South America and identifying a bioclimatic niche shift during invasion
}

\author{
FABIANA G. BARBOSA, ${ }^{1 \star}$ VALÉRIO D. PILLAR,${ }^{2}$ ANTHONY R. PALMER ${ }^{4}$ AND \\ ADRIANO S. MELO ${ }^{3}$ \\ ${ }^{1}$ Programa de Pós-Graduação em Ecologia, Instituto de Biociências, ${ }^{2}$ Departamento de Ecologia, \\ Instituto de Biociências, Universidade Federal do Rio Grande do Sul, Porto Alegre, RS, ${ }^{3}$ Departamento \\ de Ecologia, Instituto de Ciências Biológicas, Universidade Federal de Goiás, Goiânia, GO, Brazil; and \\ ${ }^{4}$ Agricultural Research Council, Animal Production Institute, Grahamstown, South Africa
}

\begin{abstract}
Eragrostis plana (Poaceae) is a perennial grass introduced from South Africa to the state of Rio Grande do Sul in southern Brazil. Currently, it is considered an invasive grass in several regions of the world, including South America, where it has caused negative ecological and socio-economic impacts. Ecological niche models, using bioclimatic variables, are often used to predict the potential distribution of invasive species. In this study we prepared two bioclimatic models for E. plana using the Genetic Algorithm for Rule-set Production, the first based on data from its native region (South Africa) and the second on data from both the native and invaded (South America) regions. We then projected each model onto South America to identify regions vulnerable to invasion by the species, and compared our results with available records of the species in South America. Finally, we explored the model's predictions for the existence of a bioclimatic niche shift during the invasion process of $E$. plana in South America, using multivariate statistical analysis. The model created with native distribution data was only able to predict (with highly suitable habitat) the region of introduction of E. plana in South America. However, the current distribution, as well as the region of introduction of the species, was reliably predicted by the model created with data from both native and invaded regions. Our multivariate analysis supports a hypothesis of bioclimatic niche shift during the invasion process of E. plana in South America.
\end{abstract}

Key words: bioclimatic variable, ecological niche model, GARP, invasive grass, native pasture.

\section{INTRODUCTION}

Biological invasions by exotic grasses are a threat to the maintenance of biodiversity (D'Antonio \& Vitousek 1992; Pivello et al. 1999). They can negatively affect the native community structure (Brewer 2008; Hoffmann \& Haridasan 2008; Yoshioka et al. 2010) and ecosystem properties and processes (Williams \& Baruch 2000; Holly et al. 2009), as well as cause many negative impacts on human economic activities (Pimentel et al. 2001).

Species of African grasses have been introduced accidentally or intentionally in different parts of the world (D’Antonio \& Vitousek 1992; Pivello et al. 1999; Williams \& Baruch 2000). In many instances, these grasses spread successfully and displaced native plants (Lenz

\footnotetext{
${ }^{\star}$ Corresponding author. Present address: Laboratório de Estatística Ambiental, Instituto de Matemática, Estatística e Física, Universidade Federal do Rio Grande. CP 474, Rio Grande, RS 96201900, Brazil (Email: fabibarbos@gmail.com)

Accepted for publication March 2012.

(C) 2012 The Authors
}

Austral Ecology (C) 2012 Ecological Society of Australia et al. 2008) and caused problems for native herbivores (Yoshioka et al. 2010). South America harbours several invasive grasses native to South Africa, including Digitaria decumbens Stent., Eragrostis ciliaris (L.) R. Brown, Eragrostis plana Nees, Hyparrhenia rufa (Nees) Stapf., Panicum coloratum L., Panicum maximum Jacq., and Rhynchelytrum repens (Willd.) C.E. Hubb. (Filgueiras 1990; Williams \& Baruch 2000).

Eragrostis plana, known as fan lovegrass (or capimannoni in Brazil), is a perennial grass (Kissmann 1991) native to South Africa (Reis \& Coelho 2000; Medeiros et al. 2004). It was introduced into the state of Rio Grande do Sul in southern Brazil in 1957 (Reis \& Coelho 2000), as a contaminant of forage seed (Chloris gayana Kunth and Eragrostis curvula Schrader) imported from South Africa (Ferreira et al. 2008a,b). In 1971, the species was identified as a high-potential forage species and was propagated and marketed as seed in several regions of Rio Grande do Sul and other states of Brazil (Paraná, Mato Grosso and Santa Catarina States) (Medeiros et al. 2009).

Eragrostis plana has low forage quality compared with native species that are abundant in natural 
grasslands in southern Brazil (Reis \& Coelho 2000; Medeiros \& Focht 2007; Medeiros et al. 2009). In addition, the species has various undesirable traits of an invasive grass that confer a competitive advantage over local species, sometimes resulting in a monoculture (Reis \& Coelho 2000), including rapid growth, a long reproductive phase (Reis \& Coelho 2000), a potential allelopathic effect (Ferreira et al. 2008a), and a persistent seed bank (Kissmann 1991; Ferreira et al. 2008b). In 1979, the sale of seeds and seedlings of the species was banned in Rio Grande do Sul by the Brazilian Ministry of Agriculture (Reis \& Coelho 2000). The species is currently an invasive grass in several regions of Asia, India, South America, and the USA (Boechat \& Longhi-Wagner 2000; USDA 2009). Because of the ecological and socio-economic threat, as well as the difficulty of control or eradication once it has become established (Reis \& Coelho 2000; Medeiros et al. 2009), it is important to explore the potential of E. plana to invade new areas. This information can be used to impede or, to be more realistic, postpone the invasion of suitable areas.

In recent years, studies have evaluated ecological niche models based on bioclimatic variables, know as bioclimatic models, to predict the potential distribution of invasive plants (Thuiller et al. 2005; Baret et al. 2006; Broennimann \& Guisan 2008). These models combine species presence and absence records and bioclimatic spatial response surfaces to create a predictive model of a species requirements for the predictors examined. The resulting model is then projected onto a new geographical space, as a habitat suitability map of the species (Sillero 2011).

Models are usually created with occurrence records and bioclimatic predictors of the native region of a plant species, to predict its invasive potential (Peterson et al. 2003; Fonseca et al. 2006; Raimundo et al. 2007), assuming climatic niche conservation across space and time. However, some models created with occurrence records and bioclimatic predictors of the native region have been able to predict accurately regions of introduction, but not the total region of invasion (Broennimann et al. 2007; Estrada-Peña et al. 2007), raising the possibility that a species may alter its climatic niche during the invasion process. Accordingly, studies have suggested that a better methodology for prediction of potential regions subject to species invasions is the use of occurrence records and bioclimatic predictors from both native and invaded regions to create bioclimatic models (Broennimann \& Guisan 2008). Studies of bioclimatic models have used additional analyses, such as measures of niche overlap and multivariate statistical analysis, to evaluate the hypothesis that a species may alter its climatic niche during the invasion process (Broennimann et al. 2007; Broennimann \& Guisan 2008; Beaumont et al. 2009; Mata et al. 2010).

(C) 2012 The Authors

Austral Ecology (C) 2012 Ecological Society of Australia
In the present study, we developed two bioclimatic models for E. plana. The first model included occurrence records (presence-absence) from its native region (South Africa), and the second included occurrence records (presence-absence) from its native region and presence records from invaded regions in South America. We projected each bioclimatic model onto South America to identify regions vulnerable to invasion by the species, and compared our results with available records of this grass in South America. Furthermore, we explored the possibility of a bioclimatic niche shift during the invasion process of $E$. plana in South America, using multivariate statistical analysis.

\section{METHODS}

\section{Occurrence records of Eragrostis plana and bioclimatic predictors}

We obtained 4816 georeferenced occurrence records of E. plana in its native range in South Africa. The dataset comprised 2780 presence and 2036 absence records (Fig. 1). Data from invaded regions in South America included 438 georeferenced presence records of the current distribution of E. plana. This dataset comprised 417 presence records from Brazil, 20 from Uruguay, and one from Argentina. The occurrence records were obtained from field surveys in South Africa and Brazil and from databases maintained by the Global Biodiversity Information Facility (http://www.gbif. org), Instituto Hórus (http://www.institutohorus.org.br) and South African Biodiversity Institute (http://www.sanbi.org/).

We initially considered 19 bioclimatic variables as possible predictors. These were: (i) annual mean temperature, (ii) mean temperature diurnal range (mean of the monthly difference of the maximum and minimum temperatures), (iii) isothermality (mean temperature diurnal range/temperature annual range), (iv) temperature seasonality (standard deviation $\times 100)$, (v) maximum temperature of the warmest month, (vi) minimum temperature of the coldest month, (vii) temperature annual range, (viii) mean temperature of the wettest quarter, (ix) mean temperature of the driest quarter, (x) mean temperature of the warmest quarter, (xi) mean temperature of the coldest quarter, (xii) annual precipitation, (xiii) precipitation in the wettest month, (xiv) precipitation in the driest month, (xv) precipitation seasonality, (xvi) precipitation in the wettest quarter, (xvii) precipitation in the driest quarter, (xviii) precipitation in the warmest quarter, and (xix) precipitation in the coldest quarter. The bioclimatic data were obtained from the Worldclim database (Hijmans et al. 2005, available at http://www.worldclim.org) with a spatial resolution of 30 arc seconds (about $1 \mathrm{~km}^{2}$ ).

\section{Pre-processing of bioclimatic predictors}

We employed regression tree analysis and Spearman correlations to reduce the original set of bioclimatic predictors to those predictors that provided the highest predictive power 


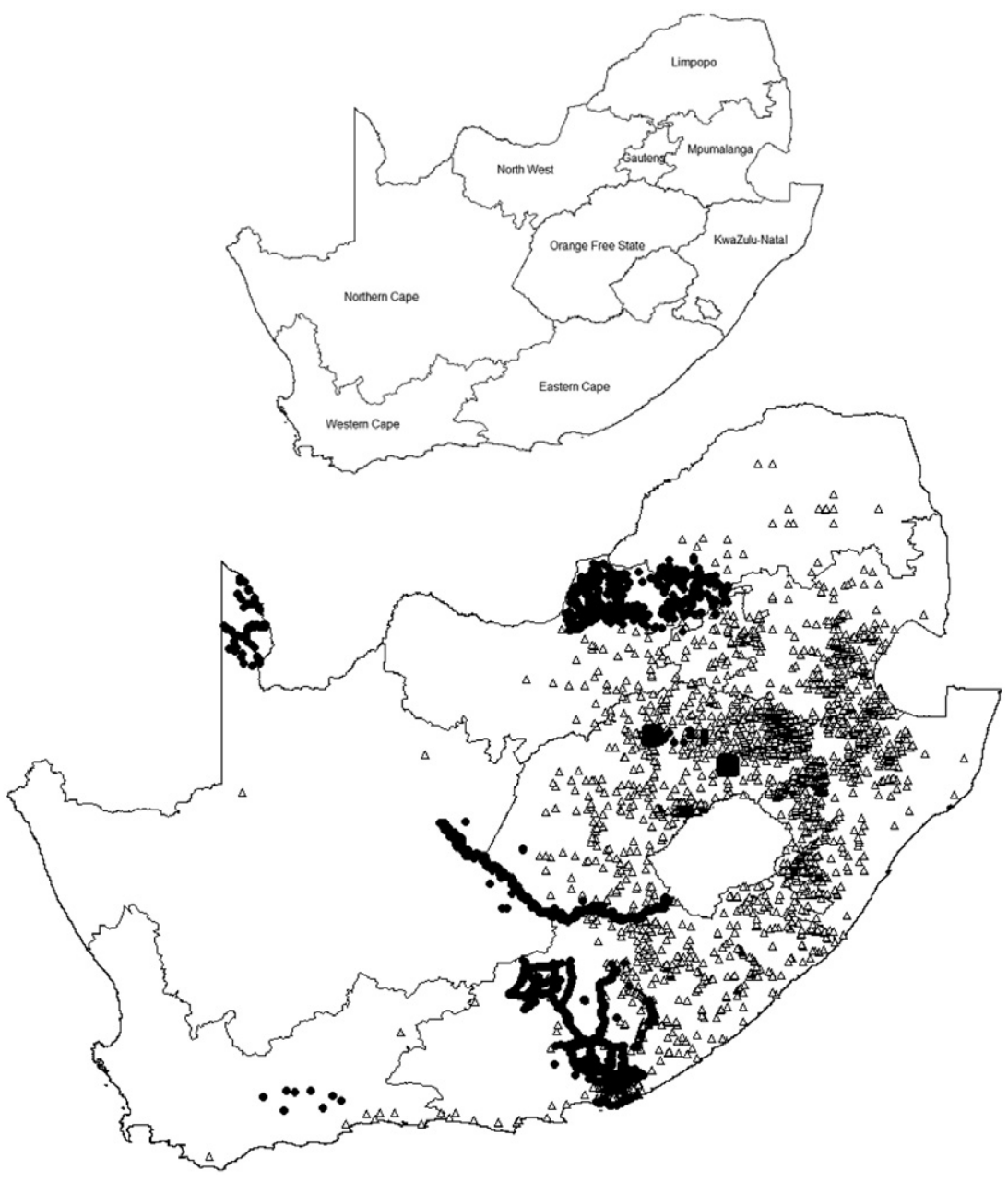

Fig. 1. Presence and absence records of Eragrostis plana in its native region of occurrence (South Africa) used to create species distribution models. $\boldsymbol{\Delta}$ = presence records. $\boldsymbol{O}=$ absence records

and that were not strongly correlated with each other. We evaluated the relationship between the occurrence records (presence and absence) of E. plana in South Africa and bioclimatic variables, using a regression tree (De'ath \& Fabricius 2000). We selected eight bioclimatic variables included in the first nodes of the resulting tree model: (i) temperature seasonality, (ii) maximum temperature of the warmest month, (iii) minimum temperature of the coldest month, (iv) mean temperature of the wettest quarter, (v) annual precipitation, (vi) precipitation in the wettest month, (vii) precipitation seasonality, and (viii) precipitation in the wettest quarter. Additionally, Spearman correlations among these eight bioclimatic variables were employed to avoid strong colinearity among predictors. We excluded one of the variables in variable pairs that had a coefficient of correlation higher than 0.8 . The reduced set of bioclimatic variables used to model the distribution of E. plana comprised: (i) temperature seasonality, (ii) minimum temperature of the coldest month, (iii) mean temperature of the wettest quarter, (iv) precipitation seasonality, and (v) precipitation in the wettest quarter.

The regression tree analysis was carried out using the package rpart (Therneau \& Atkinson 2008) run under the $R$ environment, version 2.7.2 (The R Development Core Team 2008). We used the class method, appropriate for our binary response data (presence-absence records).

\section{Bioclimatic models}

We used the Genetic Algorithm for Rule-set Production (GARP) (Stockwell \& Noble 1992) to create the two bioclimatic models. GARP applies an approach termed 'ensemble forecasting' (Araújo \& New 2007), using different types of methods (e.g. atomic, BIOCLIM, logistic regression and range rules) in an iterative machine-learning process to generate rule sets (Stockwell \& Noble 1992; Pereira \& Siqueira 2007). Through specially defined operators (e.g. crossover, mutation), the rules are iteratively combined, altered, and refined to maximize accuracy and a size-limited set of the best rules is retained (Pereira \& Siqueira 2007). This set of the best rules is used to create the final model and project onto a map to produce a habitat suitability map for the species under investigation. We used presence and absence

(C) 2012 The Authors

Austral Ecology (C) 2012 Ecological Society of Australia 
records of E. plana in its native range (South Africa) and presence records in the invaded range (South America). For each dataset (native region or native plus non-native regions), we divided equally and randomly the occurrence records into training (to create the model) and testing (to evaluate the model) datasets (Fielding \& Bell 1997; Anderson et al. 2003). The bioclimatic modelling was conducted using the algorithm GARP with best subsets (Anderson et al. 2003) run under the openModeller Desktop version 1.0.8 (http://openmodeller.sourceforge.net/) (Sutton et al. 2007).

We used the area under the curve (AUC) of a receiver operating characteristic to evaluate the predictive accuracy of fitted models (Fielding \& Bell 1997). The AUC, a criterion independent of a threshold, ranges from 0.5 (random accuracy) to a maximum value of 1.0 (perfect discrimination). The AUC values were interpreted using the classification of Pearce and Ferrier (2000): excellent AUC > 0.90; reasonable $0.70<\mathrm{AUC}<0.90$; and poor $0.50<\mathrm{AUC}<0.70$.

We projected the fitted models onto South America using five classes of habitat suitability. Additionally, we included in the resulting habitat suitability maps the currently known presence records in South America. These maps enabled us to evaluate whether the predictions matched the actual occurrences, and to identify regions with a high suitability of invasion.

\section{Bioclimatic niche shift}

We explored the similarity between presence records from native and invaded regions in terms of bioclimatic variables using principal components analysis (PCA). Additionally, we tested the hypothesis of no difference in bioclimatic niches in the native and invaded regions, using a distance-based multivariate analysis of variance (MANOVA) with randomization testing.

The PCA was carried out using the package ade4 (Dray \& Dufour 2007), run under the $\mathrm{R}$ environment, version 2.7.2 (The R Development Core Team 2008). The MANova was performed using the software MULTIV version 2.4 (Pillar 2006). We opted for the sum of squares between groups (Qb statistic according to Pillar 2006) as a criterion to assess whether the difference between groups was significant (Pillar \& Orlóci 1996). This analysis was carried out using the Euclidean distance, obtained from bioclimatic variables of the presence records used in modelling, and the data were previously transformed by centring and normalization. The randomization test was run with 1000 iterations.

\section{RESULTS}

The evaluation of the model within the native range of E. plana showed an AUC of 0.89 and 0.88 for the training and the test data, respectively, suggesting reasonable predictive power of the model. The projection of the model fitted to the data from the native region onto South America showed a high habitat suitability in regions including the present distribution of E. plana in the region of Mesopotamia (Corrientes

(C) 2012 The Authors

Austral Ecology (C) 2012 Ecological Society of Australia
Province) in Argentina, southern and north-eastern Brazil, and Uruguay (Fig. 2). The model also indicated high habitat suitability in the lowlands along the Andes, Pampas region (Buenos Aires, Cordoba and Santa Fe Province) in Argentina, Bolivia and Paraguay, where presence-absence records are not currently available. A few records from central-western Brazil were located in regions predicted by the model as having a low habitat suitability (Fig. 2).

The model built for the invaded range of $E$. plana in South America using data from both native and invaded regions showed an AUC of 0.92 and 0.91 for the training and the test data, respectively, suggesting excellent predictive power of the model. The projection of the model onto South America showed a high habitat suitability of $E$. plana in all regions where it is currently recorded (the Mesopotamia region in northeastern Argentina, southern Brazil and Uruguay), including the few records in central-western Brazil that were not predicted by the previous model (Fig. 3). The model also predicted a high habitat suitability of E. plana in regions where it is currently known to be absent, such as in the state of Rondônia (Brazil), including parts of regions identified with the previous model (Fig. 3). Given the proximity to southern Brazil, where the species is widespread, these regions are likely to be invaded by the species in the future. In relation to the model fitted to the data from the native region alone, there was an increase in the region suitable for the spread of the species. In particular, many areas of savanna (Cerrado), in the centre of South America, are now predicted to have high habitat suitability. The detached area of savanna north of the Amazon Forest (the state of Roraima in Brazil, close to Venezuela) was also predicted to be suitable for E. plana.

The PCA indicated different bioclimatic conditions between the presence records in South Africa and in South America (Fig. 4). The MANOVA test rejected the hypothesis of no difference in the bioclimatic niches in South Africa and South America $(P=0.001)$.

\section{DISCUSSION}

The bioclimatic predictors and the GARP algorithm used to build the models performed very well in predicting the distribution of E. plana in South America. It is widely recognized that bioclimatic variables, particularly temperature and precipitation, play an important role in the prediction of the potential distribution of plant species at large scales (Thuiller et al. 2005; Broennimann et al. 2007). Our results support previous studies that reported the successful use of GARP and bioclimatic variables in the prediction of the potential distributions of invasive plant species (Peterson et al. 2003, 2008; Fonseca et al. 2006).

doi:10.1111/j.1442-9993.2012.02399.x 


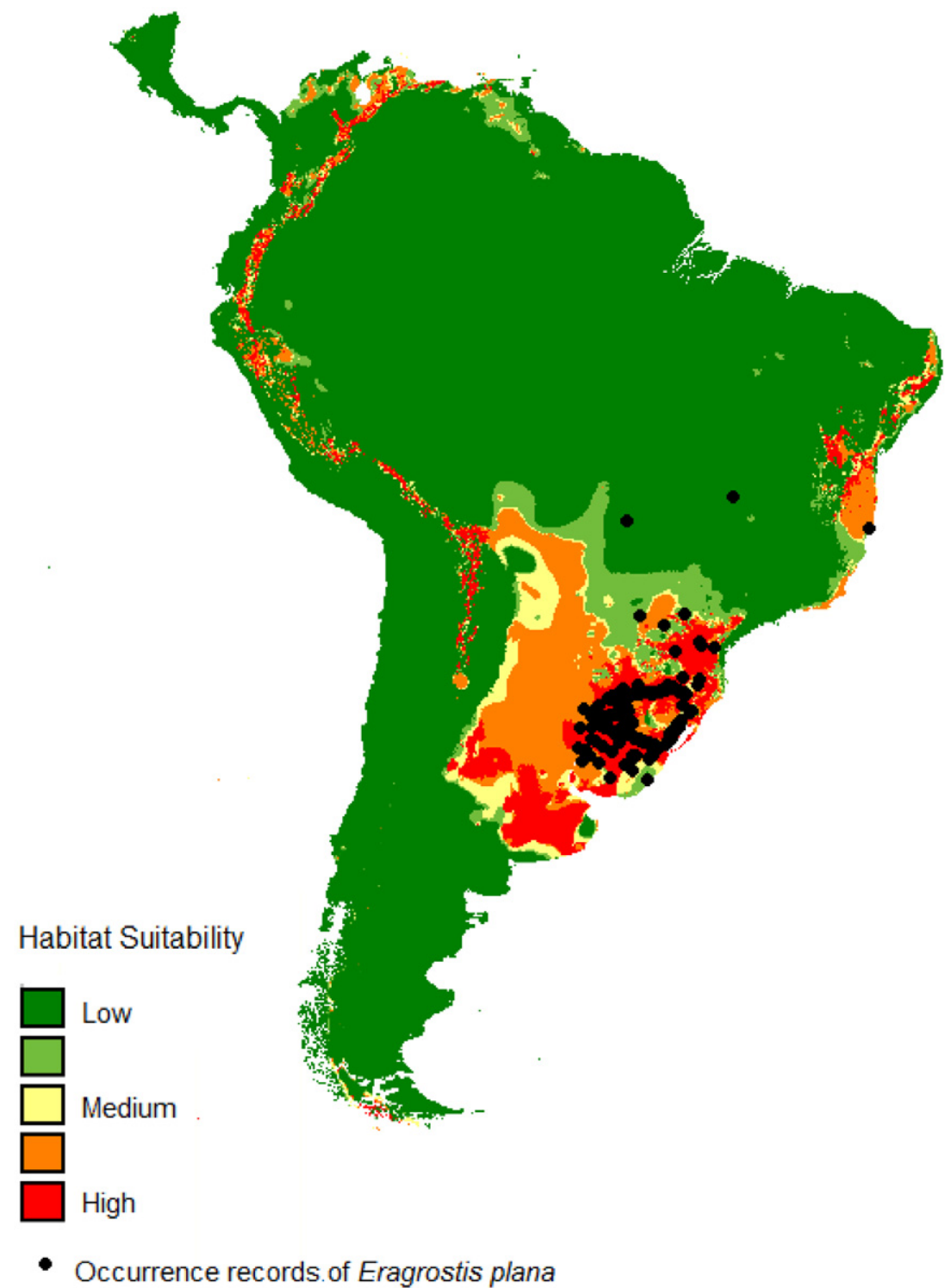

Fig. 2. Habitat suitability map of the model fitted to the distribution data of Eragrostis plana in South Africa projected onto South America. Dots indicate presence records of the species.

The model created with occurrence records and bioclimatic predictors from the native region (South Africa) was able to predict, with a high habitat suitability, the region of introduction of E. plana in South America (Rio Grande do Sul, southern Brazil), but not its current enlarged distribution. Similarly, previous studies have shown that models created with data from the native regions were able to predict region of introduction, but not the total region of invasion (Broennimann et al. 2007; Beaumont et al. 2009). Broennimann et al. (2007), for example, used occurrence records from the native region (Europe) of an invasive weed (Centaurea maculosa Lam.) in North America, and showed that the models were able to correctly predict the region of introduction in the USA, but not the full extent of the occupied region after invasion.

The current distribution and the region of introduction (Rio Grande do Sul, Brazil) of E. plana are predicted with a high habitat suitability by our model created with occurrence records and bioclimatic predictors from both native (South Africa) and invaded (South America) regions. This result is consistent with that of Broennimann and Guisan (2008), who found better prediction of the distribution of an invasive weed using models created with both native and invaded ranges than with models created with only the native range. Models created with both native and 


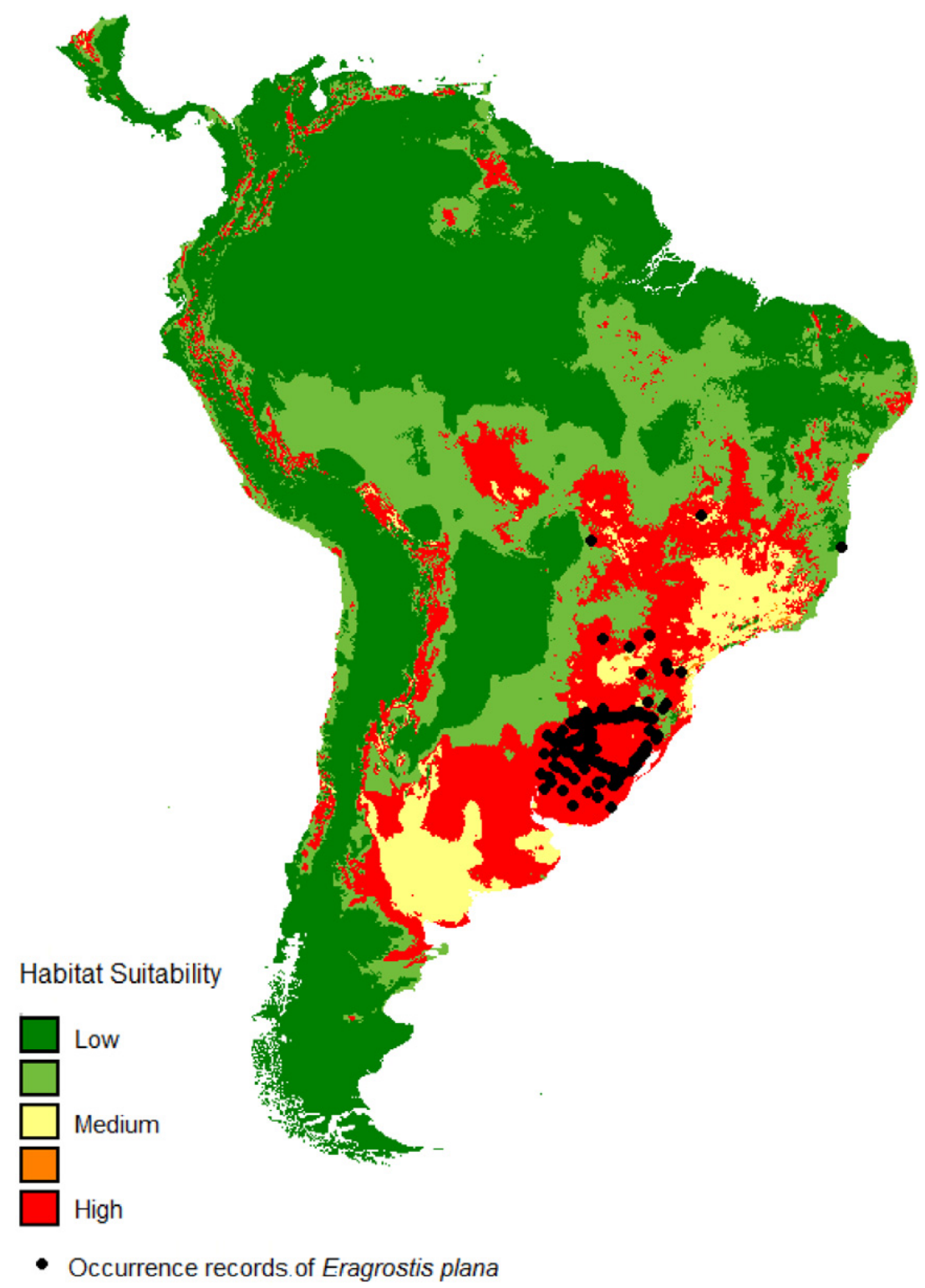

Fig. 3. Habitat suitability map of the model fitted to the distribution data of Eragrostis plana in South Africa and South America, projected onto South America. Dots indicate presence records of the species.

invaded ranges may better represent the range of bioclimatic conditions under which the species can spread (Broennimann \& Guisan 2008; Beaumont et al. 2009), because a species may shift its bioclimatic niche during the invasion process (Broennimann et al. 2007).

Previous studies of ecological niche models using additional analyses, such as measures of niche overlap and multivariate statistical analysis, have shown evidence of a bioclimatic niche shift during the invasion process of species (Broennimann et al. 2007; Beaumont et al. 2009; Mata et al. 2010). Our multivariate analysis supports a hypothesis of a bioclimatic niche shift during the invasion of E. plana into South America. This niche shift may be a consequence of various processes, including the absence of enemies and competitors from its native range in the invaded region and/or a rapid evolutionary change after introduction. In the former case, previous studies have concluded that the absence of native herbivores, pathogens, and predators may explain the invasion and spread of plant species (Keane \& Crawley 2002; Mitchell \& Power 2003). In the latter case, founding effects and evolutionary processes associated with small populations may lead to rapid adaptive evolutionary changes during the invasion process (Lee 2002).

Eradication and/or control of an invasive species after its establishment is costly and often difficult to 


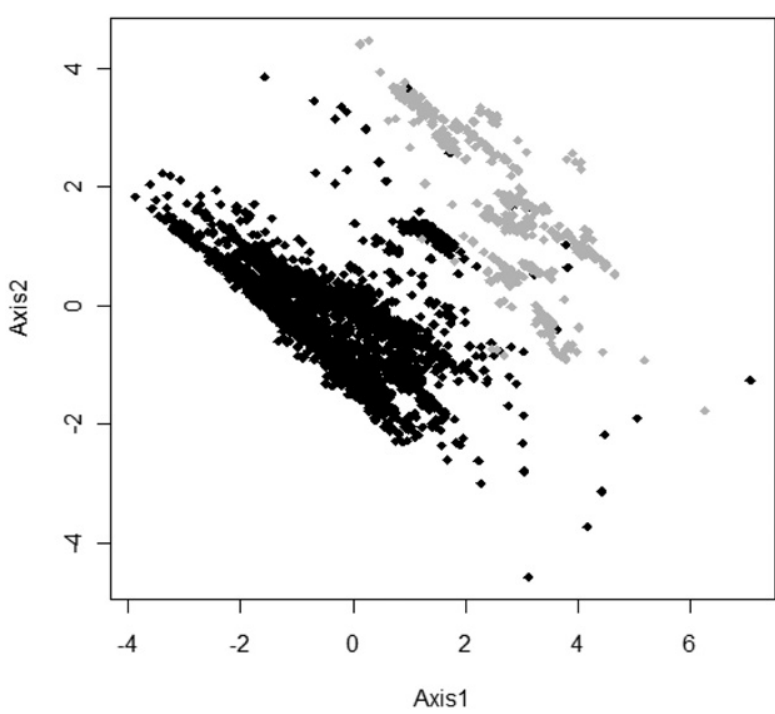

Fig. 4. Principal components analysis (PCA) of the bioclimatic conditions for the presence records of Eragrostis plana in its native (South Africa) and invaded (South America) regions. Black dots indicate records in the native bioclimatic niche, and grey dots indicate invaded bioclimatic niche.

implement (Pimentel et al. 2001). Prevention is the best management strategy, and is often the most costeffective approach (Davies \& Sheley 2007). Our model indicated uninvaded regions in South America that have favourable conditions for the establishment of E. plana. Parts of these regions are near presently infested areas. These regions need effective programmes to prevent the spread of the species by monitoring and control of its main routes of dispersal, and developing better practices of pasture management (Medeiros et al. 2009).

\section{ACKNOWLEDGEMENTS}

Janet Reid reviewed the manuscript. FGB received a student fellowship from the Coordenação de Aperfeiçoamento de Pessoal de Nível Superior (CAPES). ASM received a research grant and a research fellowship from the Conselho Nacional de Desenvolvimento Científico e Tecnológico (CNPQ; proc. 474560/ 2009-0, 302482/2008-3). VDP received support from CNPq (grant 306573/2009-1). Occurrence records from the state of Rio Grande do Sul were obtained with the invaluable contribution of José Carlos L. Reis and funding from EMBRAPA Clima Temperado.

\section{REFERENCES}

Anderson R. P., Lew D. \& Peterson A. T. (2003) Evaluating predictive models of species distributions: criteria for selecting optimal models. Ecol. Modell. 162, 211-32.
Araújo M. B. \& New M. (2007) Ensemble forecasting of species distributions. Trends Ecol. Evol. 22, 42-7.

Baret S., Rouget M., Richardson D. M. et al. (2006) Current distribution and extent of the most invasive alien plant species on La Réunion (Indian Ocean, Mascarene Islands). Austral Ecol. 31, 747-58.

Beaumont L. J., Gallagher R. V., Thuiller W., Downey P. O., Leishman M. R. \& Hughes L. (2009) Different climatic envelopes among invasive populations may lead to underestimations of current and future biological invasions. Divers. Distrib. 15, 409-20.

Boechat S. C. \& Longhi-Wagner H. M. (2000) Padrões de distribuição geográfica dos táxons brasileiros de Eragrostis (Poacea, Chloridoideae). Rev. Bras. Bot. 23, 177-94.

Brewer S. (2008) Declines in plant species richness and endemic plant species in longleaf pine savannas invaded by Imperata cylindrica. Biol. Invasions 10, 1257-64.

Broennimann O. \& Guisan A. (2008) Predicting current and future biological invasions: both native and invaded ranges matter. Biol. Lett. 4, 585-9.

Broennimann O., Treier U. A., Muller-Scharer H., Thuiller W., Peterson A. T. \& Guisan A. (2007) Evidence of climatic niche shift during biological invasion. Ecol. Lett. 10, 701-9.

D’Antonio C. M. \& Vitousek P. M. (1992) Biological invasions by exotic grasses, the grass/fire cycle and global change. Ann. Rev. Ecol. Syst. 23, 63-87.

Davies K. W. \& Sheley R. L. (2007) A conceptual framework for preventing the spatial dispersal of invasive plants. Weed Sci. 55, 178-84.

De'ath G. \& Fabricius K. E. (2000) Classification and Regression Trees: a powerful yet simple technique for ecological data analysis. Ecology 81, 3178-92.

Dray S. \& Dufour A. B. (2007) The ade4 package: implementing the duality diagram for ecologists. F. Stat. Softw. 22, 1-20.

Estrada-Peña G., Pegram R. G., Barré N. \& Venzal J. M. (2007) Using invaded range data to model the climate suitability for Amblyomma variegatum (Acari: Ixodidae) in the New World. Exp. Appl. Acarol. 41, 203-14.

Ferreira N. R., Medeiros R. B. \& Favreto R. (2008b) Banco de sementes do solo de margem viária dominada por capim-annoni-2 e sujeito ao controle com distúrbios no solo e introdução de gramíneas. Rev. Bras. Sementes 30, $54-63$.

Ferreira N. R., Medeiros R. B. \& Soares G. L. G. (2008a) Potencial alelopático do capim-annoni-2 (Eragrostis plana Nees) na germinação de sementes de gramíneas perenes estivais. Rev. Bras. Sementes 30, 43-50.

Fielding A. H. \& Bell J. F. (1997) A review of methods for the assessment of prediction errors in conservation presence/ absence models. Environ. Conserv. 24, 38-49.

Filgueiras T. S. (1990) Africanas no Brasil: gramíneas introduzidas da África. Cad. Geocienc. 5, 57-63.

Fonseca R. L., Guimarães P. R., Morbiolo S. R., ScachettiPereira R. \& Peterson A. T. (2006) Predicting invasive potential of smooth crotalaria (Crotalaria pallida) in Brazilian national parks based on African records. Weed Sci. 54, 458-63.

Hijmans R. J., Cameron S. E., Para J. L., Jones P. G. \& Jarvis A. (2005) Very high resolution interpolated climate surfaces for global areas. Int. F. Climatol. 25, 1965-78.

Hoffmann W. A. \& Haridasan M. (2008) The invasive grass, Melinis minutiflora, inhibits tree regeneration in a Neotropical savanna. Austral Ecol. 33, 29-36.

Holly D. C., Ervin G. N., Jackson C. R., Diehl S. V. \& Kirker G. T. (2009) Effect of an invasive grass on ambient rates of 
decomposition and microbial community structure: a search for causality. Biol. Invasions 11, 1855-68.

Keane R. M. \& Crawley M. J. (2002) Exotic plant invasions and the enemy release hypothesis. Trends Ecol. Evol. 17, 164-70.

Kissmann K. G. (1991) Eragrostis plana Nees. In: Plantas Infestantes E Nocivas: Plantas Inferiores - Monocotiledôneas, Vol. 1 (ed. K. G. Kissmann) pp. 420-3. BASF, São Paulo.

Lee C. E. (2002) Evolutionary genetics of invasive species. Trends Ecol. Evol. 17, 386-91.

Lenz T. I., Moyle-Croft J. L. \& Facelli J. M. (2008) Direct and indirect effects of exotic annual grasses on species composition of a South Australian grassland. Austral Ecol. 28, 23-32.

Mata R. A., Tidon R., Côrtes L. G., De Marco P. \& Diniz-Filho J. A. F. (2010) Invasive and flexible: niche shift in the drosophilid Zaprionus indianus (Insecta, Diptera). Biol. Invasions 12, 1231-41.

Medeiros R. B. \& Focht T. (2007) Invasão, prevenção, controle e utilização do capim-annoni-2 (Eragrostis plana Nees) no Rio Grande do Sul, Brasil. Pesqui. Agropecu. Gaúch. 13, 105-14.

Medeiros R. B., Pillar V. P. \& Reis J. C. L. (2004) Expansão de Eragrostis plana Nees (capim-annoni-2) no Rio Grande do Sul e indicativos de controle. Reunión del grupo técnico regional del Cono Sul en mejoramiento y utilización de los recursos forrajeros del área tropical y subtropical. Grupo Campos 20, 208-11.

Medeiros R. B., Saibros J. C. \& Focht T. (2009) Invasão de capim-annoni (Eragrostis plana Nees) no bioma Pampa do Rio Grande do Sul. In: Campos Sulinos - Conservação E Uso Sustentável Da Biodiversidade (eds V. P. Pillar, S. C. Müller, Z. M. S. Castilhos \& A. V. A. Jacques) pp. 319-30. Ministério do Meio Ambiente, Brasília.

Mitchell C. E. \& Power A. G. (2003) Release of invasive plants from fungal and viral pathogens. Nature 421, 625-7.

Pearce J. \& Ferrier S. (2000) Evaluating the predictive performance of habitat models developed using logistic regression. Ecol. Modell. 133, 225-45.

Pereira R. S. \& Siqueira M. F. (2007) Algoritmo genético para produção de conjuntos de regras (GARP). Megadiversidade 3, 46-55.

Peterson A. T., Papes M. \& Kluza D. A. (2003) Predicting the potential invasive distributions of four alien plant species in North America. Weed Sci. 51, 863-8.

Peterson A. T., Stewart A., Mohamed K. I. \& Araújo M. B. (2008) Shifting global invasive potential of European plants with climate change. PLoS ONE 3, e2441.

Pillar V. D. (2006) MULTIV: multivariate exploratory analysis, randomization testing and bootstrap resampling. User's Guide v. 2.4. Departamento de Ecologia, Universidade Federal do Rio Grande do Sul (UFRGS), Porto Alegre,
Brasil. [Cited 17 January 2011.] Available from URL: http:// ecoqua.ecologia.ufrgs.br

Pillar V. D. \& Orlóci L. (1996) On randomization testing in vegetation science: multifactor comparisons of relevé groups. F. Veg. Sci. 7, 585-92.

Pimentel D., McNair S., Janecka S. et al. (2001) Economic and environmental threats of alien plant, animal and microbe invasions. Agric. Ecosyst. Environ. 84, 1-20.

Pivello V. R., Shida C. N. \& Meirelles S. T. (1999) Alien grasses in Brazilian savannas: a threat to the biodiversity. Biodivers. Conserv. 8, 1281-94.

Raimundo R. L. G., Fonseca R. L., Schachetti-Pereira R., Peterson A. T. \& Lewinsohn T. M. (2007) Native and exotic distributions of siamweed (Chromolaena odorata) modeled using the Genetic Algorithm for Rule-Set Production. Weed Sci. 55, 41-8.

Reis J. C. L. \& Coelho R.W. (2000) Controle Do Capim-Annoni-2 Em Campos Naturais E Pastagens. EMBRAPA Clima Temperado, Circular Técnica, Pelotas.

Sillero N. (2011) What does ecological modelling model? A proposed classification of ecological niche models based on their underlying methods. Ecol. Modell. 222, 1343-6.

Stockwell D. R. B. \&Noble I. R. (1992) Induction of sets of rules from animal distribution data: a robust and informative method of analysis. Math. Comput. Simul. 33, 385-90.

Sutton T., Giovani R. \& Siqueira M. F. (2007) Introducing openModeller. OSGeo F. 1, 1-6.

The R Development Core Team (2008) R: a language and environment for statistical computing. R Foundation for Statistical Computing, Vienna, Austria. ISBN 3-900051-07-0. [Cited 26 January 2011.] Available from URL: http://www. r-project.org

Therneau T. M. \& Atkinson B. (2008) rpart: recursive partitioning. R port by B. Ripley. R package version 3.1-41. [Cited 17 January 2011.] Available from URL: http://www. r-project.org

Thuiller W., Richardson D. M., Pysek P., Midgley G. F., Hughes G. O. \& Rouget M. (2005) Niche-based modelling as tool for predicting the risk of alien plant invasions at a global scale. Glob. Chang. Biol. 11, 2234-50.

United States Department of Agriculture (USDA) (2009) PLANTS Database (Version 3.5). [Cited 23 November 2009.] Available from URL: http://plants.usda.gov

Williams D. G. \& Baruch Z. (2000) African grass invasion in the Americas: ecosystem consequences and the role of ecophysiology. Biol. Invasions 2, 123-40.

Yoshioka A., Kadoya T., Suda S. \& Washitani I. (2010) Invasion of weeping lovegrass reduces native food and habitat resource of Eusphingonotus japonicus (Saussure). Biol. Invasions 12, 2789-96. 